\title{
PENERAPAN MODEL PEMBELAJARAN CREATIVE PROBLEM SOLVING DENGAN MEDIA VISUAL DALAM MEMAHAMI KONSEP MATEMATIKA
}

\author{
Syahmudi Louk ${ }^{1}$, Yuan Andinny ${ }^{2}$, Ihwan Zulkarnain ${ }^{3}$ \\ ${ }^{1,2,3}$ Program Studi Pendidikan Matematika, Universitas Indraprasta PGRI Jakarta \\ Email: syahmudilouk@gmail.com
}

\begin{abstract}
Abstrak:
Tujuan dari penelitian ini adalah untuk perbedaan model pembelajaran Creative Problem Solving dan model pembelajaran Konstruktivisme dalam memahami konsep matematika. Penelitian ini dilaksanakan di SMA Islam PB. Soedirman Cijantung Jakarta Timur tepatnya pada kelas X. Metode penelitian yang digunakan untuk menguji perbedaan tersebut adalah metode quasi eksperimen. Populasi siswa kelas X SMA Islam PB. Soedirman Cijantung yang dijadikan sampel sebanyak 54 siswa, dengan teknik sampling yang digunakan yaitu cluster random sampling. Instrumen penelitian yang digunakan yaitu tes kemampuan pemahaman konsep matematika dalam bentuk uraian sebanyak 10 soal yang telah diujikan sebelumnya. Berdasarkan hasil analisis dan pembahasan, maka dalam penelitian ini dapat disimpulkan bahwa berdasarkan analisis dengan uji-t, maka diperoleh $t_{\text {hitung }}>t_{\text {tabel }}$. Dari hasil pengujian tersebut diperoleh kemampuan pemahaman konsep matematika dengan menggunakan model pembelajaran Creative Problem Solving lebih tinggi dari pada model pembelajaran Konstruktivisme. Sehingga dapat disimpulkan bahwa terdapat pengaruh yang berbeda antara penerapan model pembelajaran Creative Problem Solving dan model pembelajaran Konstruktivisme terhadap kemampuan pemahaman konsep matematika.
\end{abstract}

Kata Kunci: Creative Problem Solving, Media Visual, Konsep

\section{Pendahuluan}

Seiring perkembangan ilmu pengetahuan dan teknologi yang lebih maju, berbagai upaya dilakukan dalam rangka meningkatkan sumber daya manusia yang berkualitas, salah satunya melalui pendidikan. Pendidikan memegang peranan penting dalam mempersiapkan sumber daya manusia yang berkualitas dan mampu berkompetensi dalam perkembangan ilmu pengetahuan dan teknologi, sehingga pendidikan harus dilaksanakan dengan sebaik-baiknya untuk memperolah hasil yang maksimal (Fariah \& Leonard, 2017). Perkembangan tersebut memberikan wahana yang memungkinkan matematika berkembang dengan pesat pula. Pembelajaran matematika bertujuan agar siswa memiliki kecakapan atau kemahiran matematika. Mata pelajaran matematika perlu diberikan kepada semua siswa untuk membekali mereka dengan kemampuan berpikir logis, analisis, sistematis, kritis dan kreatif serta kemampuan bekerjasama (Depdiknas, 2006). Selain itu, pembelajaran matematika digunakan untuk pengembangan kemampuan pemecahan masalah dan mengkomunikasikan ide atau gagasan dengan menggunakan simbol, tabel, diagram dan media lain.

Berdasarkan hasil TIMSS (Trends Mathematics and Science Study) tahun 2011 yang diikuti oleh siswa kelas VIII, Indonesia masuk dalam ranking 5 besar dari bawah dari 42 negara yang ikut dengan skor 386 (kompas.com, 2012). Hasil PISA (Programme for International Student Assessment) pun tidak begitu berbeda, skor matematika siswa pada PISA tahun 2015 adalah 386, dan rata-rata skor dari seluruh negara adalah 490 (OECD, 2016). Hal tersebut menandakan bahwa kemampuan matematis siswa Indonesia masih sangat rendah jika dibandingkan dengan negara lain. Permasalahan lainnya adalah proses pembelajaran masih berpusat pada guru, sehingga kemampuan-kemampuan yang ada dalam diri siswa belum bisa digali secara optimal, termasuk pemecahan masalah dan kreativitas. Noer (2009) mengatakan bahwa kreativitas siswa masih kurang mendapat perhatian guru dalam pembelajaran matematika dan guru hanya memberikan soal- soal rutin saja. Hal tersebut 
berdampak pada tidak terbiasanya siswa pada soal- soal pemecahan masalah yang membutuhkan kreativitas. Alhadad (2010) menambahkan bahwa siswa hanya dapat mengerjakan soal-soal matematika berdasarkan apa yang dicontohkan guru, jika diberikan soal yang berbeda mereka akan mengalami kesulitan dalam menyelesaikannya.

Berdasarkan pengamatan terhadap Rencana Pelaksanaan Pembelajaran (RPP) mata pelajaran matematika kelas X SMA Islam PB. Soedirman Cijantung, metode pembelajaran yang digunakan adalah ceramah, tanya jawab, diskusi dan pemberian tugas, serta sumber belajarnya adalah buku paket Matematika kelas X dan sumber buku lainnya. Menurut hasil penelitian Subandriah (2012), soal-soal pada beberapa buku ajar masih berada pada tingkat kognitif yang rendah hingga menengah. Walaupun ada tingkat kognitif yang tinggi namun konsentrasinya sangat sedikit. Hal tersebut mengindikasikan bahwa soal-soal pada buku tersebut belum sepenuhnya dapat merefleksikan Kurikulum 2013 (Kurtilas) yang telah ditetapkan oleh Pemerintah. Sejalan dengan hal itu, Suandito, (2009) mengatakan bahwa dalam buku pegangan siswa dan guru yang beredar dan digunakan, hampir semua soal pemecahan masalah dengan soal tertutup, yang kurang mengajak siswa aktif dan kreatif.

Dari uraian di atas, diperlukan adanya model pembelajaran yang dapat memfasilitasi siswa untuk dapat beraktivitas sehingga membantu mengembangkan kemampuan pemecahan masalah dan juga menumbuhkan kreativitas siswa. Salah satu model pembelajaran yang dapat membantu siswa lebih aktif, mengembangkan kemampuan pemecahan masalah dan kreativitas adalah creative problem solving atau sering disingkat CPS. Menurut Treffinger, Isaksen, dan Dorval (2006), "CPS didasarkan pada landasan yang kuat tentang teori dan penelitian tentang kreativitas dan pemecahan masalah".

CPS dapat diartikan sebagai suatu cara yang baru dan unik untuk menyelesaikan suatu masalah yang dihadapi (Isrok'atun, 2012). Isrok'atun menambahkan bahwa CPS lebih menekankan pada berbagai macam alternatif ide atau gagasan untuk berbagai kemungkinan dalam proses pemecahan masalah. Dengan menerapkan CPS dalam pembelajaran diharapkan dapat menimbulkan pemahaman dalam pemecahan masalah sekaligus kreativitas dan keaktifan siswa dalam mempelajari matematika, sehingga siswa dapat memperoleh manfaat yang maksimal baik dari proses maupun hasil belajarnya.

"CPS comes from studying what people really need to do to solve problems creatively in the world..." (Treffinger, Isaksen, dan Dorval, 2006) yang berarti CPS berasal dari mempelajari apa yang sangat dibutuhkan orang untuk dilakukan dalam memecahkan masalah di dunia. Mereka menambahkan "semua orang bisa menggunakan CPS yang akan membantu dalam kehidupan sehari-hari, di rumah dan di keluarga dan juga pekerjaan atau karir". Hal tersebut berarti bahwa CPS dapat diterapkan pada berbagai hal dalam kehidupan, termasuk pembelajaran matematika. Menurut Treffinger dan Isaksen (2005), “CPS telah berhasil diterapkan dalam pendidikan, dari perguruan tinggi sampai Sekolah dasar". Sehingga CPS tentunya dapat diterapkan dalam pembelajaran matematika, termasuk trigonometri.

Berdasarkan pengalaman saat Praktik Pengalaman Lapangan di SMA Islam PB. Soedirman Cijantung Jakarta Timur pada bulan Februari-Mei 2019, kemampuan pemecahan masalah siswa masih tergolong rendah. Misalnya pada pengerjaan soal: Kakek mempunyai sebuah taman bermain berbentuk segitiga yang diketahui kelilingnya adalah $16 \mathrm{~m}$. Taman bermain itu dibatasi titik $A, B$ dan $C$. Panjang sisi $B C$ adalah $3 \mathrm{~m}$ lebih panjang dari panjang sisi $A C$, sedangkan panjang sisi $A B$ adalah $4 \mathrm{~m}$ lebih panjang dari panjang sisi AC. Tentukan luas taman bermain tersebut!

Hasil jawaban siswa ditunjukkan 
pada Gambar 1 berikut.

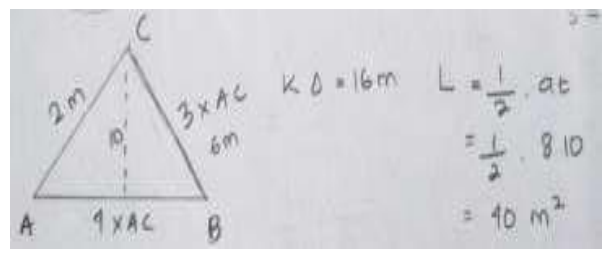

Gambar 1. Contoh Hasil Pekerjaan Siswa

Pada Gambar 1 di atas, terlihat bahwa siswa tidak menuliskan apa yang diketahui dan ditanyakan dari masalah, artinya siswa belum bisa memahami masalah. Selain itu siswa belum bisa menjelaskan konsep apa yang digunakan dalam menyelesaikan soal tersebut, artinya siswa belum bisa merencanakan penyelesaian dan melaksanakan rencana penyelesaian. Jika dilihat dari gambar, siswa juga belum menyimpulkan hasil yang diperoleh, artinya siswa belum mampu melihat kembali hasil dan proses. Padahal memahami masalah, merencanakan penyelesaian, melaksanakan rencana penyelesaian, dan melihat kembali hasil dan proses termasuk bagian dari pemecahan masalah matematika menurut Polya.

Sebagian besar siswa mengalami masalah pada saat menyelesaikan soal matematika. Siswa cenderung untuk menggunakan rumus atau cara cepat yang sudah biasa digunakan daripada menggunakan langkah prosedural dari penyelesaian masalah matematika. Sementara, kemampuan menyelesaikan soal pada materi trigonometri masih lemah, maka dari itu perlu dilakukan perbaikan agar penguasaan materi dan penyelesaian masalah trigonometri dapat meningkat. Guru ikut serta dalam proses memperbaiki penguasaan materi trigonometri, yakni dengan memperbaiki kegiatan pembelajaran disekolah.

Salah satu usaha untuk memperbaiki proses pembelajaran adalah dengan memilih model pembelajaran yang tepat dan inovatif dalam pembelajaran matematika. Salah satu model pembelajaran yang dapat diterapkan guna meningkatkan pemahaman konsep kemampuan pemecahan masalah matematika adalah
Model Pembelajaran Creative Problem Solving.

Berdasarkan uraian permasalahan tersebut, peneliti tertarik untuk melakukan penelitian dengan judul "Penerapan Model Pembelajaran Creative Problem Solving (CPS) dengan Media Visual dalam Memahami Konsep Matematika di SMA Islam PB. Soedirman Cijantung Jakarta Timur".

\section{Metode Penelitian}

Penelitian ini dilakukan di SMA Islam PB. Soedirman yang terletak di Cijantung, Jakarta Timur. Penelitian ini dilaksanakan pada semester genap tahun ajaran 2018/2019, selama 5 bulan mulai bulan April sampai bulan Agustus. Sedangkan Metode penelitian yang digunakan dalam penelitian ini adalah metode penelitian quasi eksperimen. Metode ini mempunyai kelompok kontrol, tetapi tidak berfungsi sepenuhnya mengontrol variabel-variabel luar yang mempengaruhi pelaksanaan eksperimen.

Peneliti akan mencari hasil tes kemapuan pemahaman konsep matematika siswa dengan media visual menggunakan model pembelajaran Creative Problem Solving, kemudian membandingkan dengan hasil tes kemampuan pemahaman konsep matematika siswa yang diajarkan menggunakan model pembelajaran Konstruktivisme.

Sedangkan desain penelitian yang digunakan adalah randomized posttest only control group design. Desain penelitian tersebut sebagai berikut:

Tabel 1. Desain Peneliti

\begin{tabular}{ccc}
\hline $\mathbf{X}_{1}$ & $\mathbf{E}_{1}$ & $\mathbf{Y}_{1}$ \\
\hline $\mathbf{X}_{2}$ & $\mathbf{E}_{2}$ & $\mathbf{Y}_{2}$ \\
\hline
\end{tabular}

Keterangan :

$\mathrm{X}_{1}=$ Kelas eksperimen

$\mathrm{X}_{2}=$ Kelas kontrol

$\mathrm{E}_{1}=$ Perlakuan dengan model pembelajaran creative problem solving 
$\mathrm{E}_{2}=$ Perlakuan dengan model pembelajaran konstruktivisme

$\mathrm{Y}_{1}=$ Hasil post test tes kemampuan pemahaman konsep matematika kelas eksperimen

$\mathrm{Y}_{2}=$ Hasil post test tes kemampuan pemahaman konsep matematika kelas kontrol
Populasi sampel yang digunakan dalam penelitian ini sebanyak 54 peserta didik, dengan teknik sampling. Instrumen yang digunakan adalah tes soal essay tentang perbandingan trigonometri yang mengarah pada kemampuan pemahaman konsep matematika kelas $\mathrm{X}$. Instrumen sebelumnya divalidasi terlebih dahulu, sehingga sebanyak 10 soal telah valid teknik analisa data.

\section{Hasil dan Pembahasan \\ Hasil}

Tabel 2. Perbandingan Kemampuan Pemahaman Konsep Matematika Kelompok Eksperimen CPS dan Kelompok Kontrol Konstruktivisme

\begin{tabular}{ccc}
\hline Statistik & Eksperimen CPS & Kontrol Konstruktivisme \\
\hline Banyak sampel & 30 & 24 \\
Nilai terendah & 38 & 31 \\
Nilai tertinggi & 95 & 89 \\
Mean & 71,5 & 60,92 \\
Median & 75,5 & 63,36 \\
Modus & 82,5 & 67,17 \\
Varians & 271,38 & 162,44 \\
Simpangan Baku & 16,47 & 12,75 \\
\hline
\end{tabular}

Sebelum melakukan pengujian hipotesis dengan uji t, maka diperlukan pengujian persyaratan analisis yang dilakukan yaitu uji normalitas dan homogenitas varians. Uji normalitas yang digunakan adalah uji liliefors, uji ini digunakan untuk mengetahui apakah data yang diperoleh pada penelitian berdistribusi normal atau tidak. Menurut Supardi (2013: 141), kriteria pengujian data Terima $\mathrm{H}_{0}$ jika $\mathrm{L}_{0}<\mathrm{L}_{\text {tabel }}$ berdistribusi dan Tolak $\mathrm{H}_{0}$ jika $\mathrm{L}_{0}$ $>\mathrm{L}_{\text {tabel }}$ berdistribusi. Hal ini dapat dilihat pada tabel 3 di bawah ini:

Tabel 3. Ringkasan Hasil Uji Normalitas

\begin{tabular}{lccrrl}
\hline \multicolumn{1}{c}{ Kelas } & Jumlah & $\begin{array}{c}\text { Taraf } \\
\text { Signifikan }\end{array}$ & $\mathrm{L}_{\text {hitung }}$ & $\mathrm{L}_{\text {tabel }}$ & Keterangan \\
& Sampel & 0,05 & 0,1193 & 0,173 & $\mathrm{H}_{0}$ diterima \\
\hline Eksperimen & 30 & 0,05 & 0,1344 & 0,190 & $\mathrm{H}_{0}$ diterima \\
Kontrol & 24 & & & & \\
\hline
\end{tabular}

Berdasarkan Tabel 3, dapat dilihat bahwa kemampuan pemecahan masalah pada kelas eksperimen dan kelas kontrol memiliki nilai $\mathrm{L}_{\text {hitung }}<\mathrm{L}_{\text {tabel }}$, sehingga dapat disimpulkan bahwa terima $\mathrm{H}_{0}$ maka kedua data berdistribusi normal.

Setelah kedua kelas sampel berasal dari populasi yang berdistribusi normal, maka selanjutnya dilakukan uji homogenitas. Menurut Supardi (2013: 142) pengujian homogenitas dilakukan dalam rangka menguji kesamaan varians setiap kelompok data. Persyaratan uji homogenitas diperlukan untuk melakukan analisis inferensial dalam uji komparasi. Dalam hal ini pengujian yang dilakukan ialah uji $\mathrm{F}$ (Fisher) karena hanya memiliki 2 (dua) kelompok data/ sampel antara kelas eksperimen dan kelas kontrol. Dengan kriteria pengujiannya yaitu $F_{\text {hitung }}<F_{\text {tabel }}$ terima $H_{o}$, maka data bersifat homogen $F_{\text {hitung }}>F_{\text {tabel }}$ tolak $H_{o}$, maka data tidak bersifat homogen. Hal ini dapat dilihat pada Tabel 4 di bawah ini: 

Tabel 4. Ringkasan Hasil Perhitungan Uji Homogenitas

\begin{tabular}{lccccc}
\hline \multicolumn{1}{c}{ Kelas } & $\begin{array}{c}\text { Jumlah } \\
\text { Sampel }\end{array}$ & Varians & Fhitung & Ftabel & Keterangan \\
\hline Eksperimen & 30 & 271,38 & 1,671 & 1,967 & $\mathrm{H}_{0}$ diterima \\
Kontrol & 24 & 162,44 & & & \\
\hline
\end{tabular}

Berdasarkan Tabel 4, terlihat $F_{\text {hitung }}$ $<F_{\text {tabel }}$ terima $H_{o}$, maka data bersifat homogen. Pengujian hipotesis penelitian berdasarkan hasil perhitungan uji- $t$ tersebut diperoleh nilai $t_{\text {hitung }}$ sebesar 2,5859 sedangkan nilai $t_{\text {tabel }}$ sebesar 1,6747 . Karena $t_{\text {hitung }}>t_{\text {tabel, }}$ maka tolak $H_{0}$, dengan demikian dapat ditarik kesimpulan bahwa terdapat pengaruh kemampuan pemahaman konsep matematika pada pokok bahasan perbandingan trigonometri yang menggunakan model pembelajaran Creative Problem Solving (kelas eksperimen) dengan model pembelajaran Konstruktivisme (kelas kontrol). Dari kesimpulan tersebut dapat dikatakan bahwa dalam penelitian ini, model pembelajaran Creative Problem Solving lebih tinggi dari model pembelajaran Konstruktivisme.

\section{Pembahasan}

Penelitian penerapan model CPS pada pembelajaran matematika ini bertujuan untuk mengetahui aktivitas siswa selama pembelajaran dan mengetahui kemampuan pemahaman konsep pada pemecahan masalah siswa setelah pembelajaran dengan penerapan model CPS materi perbandingan trigonometri di kelas $X$ SMA Islam PB Soedirman Cijantung Jakarta Timur. Data diperoleh melalui hasil observasi selama pembelajaran berlangsung dan melalui tes soal kemampuan pemahaman konsep materi perbandingan trigonometri.

Berdasarkan hasil analisis data observasi aktivitas siswa yang dikategorikan sangat baik dapat dilihat bahwa hampir seluruh deskriptor tampak pada pembelajaran dengan menerapkan model CPS. Aktivitas siswa yang dikategorikan baik tidak jauh berbeda dengan aktivitas siswa dengan kategori sangat baik. Hanya saja beberapa deskriptor pada tahapan CPS tidak tampak. Pada saat proses pembelajaran, siswa dengan kategori sangat baik dan baik ini cenderung aktif mengikuti proses pembelajaran dan diskusi. Ini dapat dilihat dari tahap klarifikasi, siswa mampu memahami masalah dari permasalahan yang disajikan dengan menulis hal-hal yang diketahui dan ditanyakan. Kemudian pada tahap mengeksplorasi ide, siswa mampu memberikan ide-ide atau gagasan terkait permasalahan yang disajikan. Siswa juga dapat memberikan ide yang relevan lebih dari satu ide. Selanjutnya pada tahap mengembangkan, siswa dapat memilih ide yang paling tepat berdasarkan hasil diskusi, lalu selanjutnya mampu mengimplementasikan ide yang dipilih untuk menyelesaikan permasalahan yang disajikan. Dengan begitu dapat dikatakan bahwa aktivitas siswa ini berada dalam kategori sangat baik dan baik dalam proses pembelajaran dengan menerapkan CPS. Hal tersebut sejalan dengan Widiani (2016) dan Kiftiyah dkk (2014) bahwa proses pembelajaran yang baik dengan menerapkan CPS mampu memberikan pengaruh dan peningkatan aktivitas belajar siswa.

Kemudian, siswa yang masuk dalam kategori aktivitas belajar siswa cukup dan kurang sebenarnya telah mengikuti proses pembelajaran dengan cukup baik, hanya saja terdapat beberapa deskriptor dari empat tahapan CPS yang tidak muncul. Selain itu siswa cenderung enggan untuk berdiskusi dengan rekan sekelompoknya. Salah satu faktor yang menyebabkan hal tersebut adalah adanya beberapa siswa yang menonjol dalam proses diskusi. Hal tersebut sejalan dengan pendapat Suryobroto (2009) yang mengatakan bahwa salah satu kelemahan metode diskusi adalah jalannya diskusi didominasi oleh beberapa siswa yang menonjol. Padahal proses diskusi ini sangat penting dalam pembelajaran dengan menerapkan CPS. 
Selanjutnya, perbandingan kemunculan tahapan model CPS yang paling tinggi adalah pada tahap mengembangkan (Develop) yaitu dengan kategori baik, sedangkan yang paling rendah adalah pada tahap implementasi dengan kategori cukup. Hal tersebut terlihat dari proses belajar siswa dalam kelompok. Beberapa kelompok mampu memilih ide yang akan digunakan untuk menyelesaikan masalah. Namun pada tahap selanjutnya, siswa kurang mampu untuk menggunakan ide yang telah dipilih untuk menyelesaikan permasalahan yang disajikan.

Secara umum, berdasarkan hasil analisis data tes kemampuan pemecahan masalah siswa dengan kategori kurang disebabkan karena belum mampu memahami masalah yang disajikan dengan baik. Hal tersebut sesuai dengan pendapat Herman (2000) yaitu tanpa adanya pemahaman terhadap masalah yang disajikan, siswa akan mengalami kesulitan dalam menyelesaikan masalah tersebut dengan benar. Dampak yang terjadi dari kurang mampunya siswa memahami masalah yang disajikan adalah siswa kesulitan dalam menyusun dan melaksanakan rencana. Padahal kunci utama dari menyelesaikan sebuah masalah adalah menggali ide-ide kemudian menyusun rencana (Polya, 1973; Isro'atun, 2012). Siswa juga belum terbiasa mengerjakan soal-soal pemecahan masalah yang memiliki beberapa cara penyelesaian yang berbeda atau solusi yang tidak tunggal, meskipun pada proses pembelajaran dengan menggunakan CPS, siswa telah diberikan permasalahan yang serupa.

Selanjutnya, berdasarkan hasil analisis tes siswa, terlihat bahwa kemunculan indikator kemampuan pemecahan masalah yang paling rendah terletak pada aspek memeriksa jawaban. Hal tersebut terjadi karena pada proses pembelajaran dengan menggunakan model CPS tidak terdapat tahapan memeriksa jawaban kembali seperti yang terdapat pada indikator kemampuan pemecahan masalah. Sehingga siswa tidak terbiasa untuk melakukan langkah memeriksa kembali jawaban mereka, akibatnya pada saat tes kemampuan pemecahan masalah dengan prosedur Polya, hampir sebagian besar siswa tidak melakukan langkah memeriksa jawaban kembali. Selain itu berdasarkan hasil penelitian Wahyuni, dkk (2012), Gumilang (2016) menunjukkan bahwa sebagian besar siswa tidak memeriksa hasil jawaban mereka. Siswa lebih terbiasa untuk menuliskan hal-hal yang diketahui, ditanyakan dan menjawab soal secara langsung.

Berdasarkan hasil penelitian yang telah dilakukan sebelumnya, pembelajaran dengan menerapkan model CPS mampu memberikan pengaruh dan peningkatan kemampuan pemecahan masalah siswa ( Pujiadi, 2008; Khanifah, 2011). Selanjutnya Herman (2000) mengemukakan bahwa kemampuan pemecahan masalah diperoleh dari banyaknya pengalaman dalam memecahkan berbagai masalah. Oleh karena itu, pembelajaran dengan menerapkan model CPS mungkin akan memberikan hasil yang lebih baik jika dilakukan tidak hanya pada satu atau dua sub materi pembelajaran saja, dan dilakukan dalam jangka waktu yang lebih lama, serta memperbanyak latihan soal-soal pemecahan masalah.

Dari proses kegiatan penelitian yang telah dilakukan, peneliti melihat beberapa kendala yang mengakibatkan rendahnya aktivitas siswa dan kemampuan pemecahan masalah beberapa siswa yaitu Lembar Kerja Peserta Didik (LKPD) yang telah disesuaikan dengan model CPS yang diberikan, belum mampu membiasakan siswa dalam mengerjakan soal pemecahan masalah dengan prosedur Polya, terutama pada indikator memahami masalah dan memeriksa kembali jawaban. Sehingga pada saat tes kemampuan pemecahan masalah, masih banyak siswa yang melewatkan langkah tersebut. Selanjutnya, pada proses pembelajaran dengan menggunakan CPS, langkah memeriksa jawaban dengan prosedur Polya tersebut tidak tampak, karena CPS hanya terdiri dari empat tahap yang didalamnya tidak terdapat langkah memeriksa kembali jawaban.

Model pembelajaran Creative Problem Solving (CPS) merupakan variasi dari pembelajaran pemecahan masalah 
melalui teknik sistematik dalam mengorganisasikan gagasan kreatif untuk menyelesaikan suatu permasalahan. Secara umum sintaksnya adalah dimulai dari fakta actual sesuai dengan materi bahan ajar melalui tanya jawab lisan, identifikasi permasalahan dan focus pilih, mengolah pikiran sehingga muncul gagasan baru untuk menentukan solusi, presentasi dan diskusi. Dengan menggunakan model CPS siswa diajarkan empat langkah pemahaman dan pengaturan diri spesifik, yaitu: (1) Klarifikasi masalah, meliputi pemberian penjelasan kepada siswa tentang masalah yang diajukan, agar siswa dapat memahami tentang penyelesaian seperti apa yang diharapkan, (2) Pengungkapan pendapat, tahap ini siswa dibebaskan untuk mengungkapkan pendapat tentang berbagai macam strategi penyelesaian masalah,(3) Evaluasi dan Pemilihan, pada tahap ini setiap kelompok mendiskusikan pendapatpendapat atau strategi-strategi mana yang cocok untuk menyelesaikan masalah, (4) Implementasi, Pada tahap ini siswa menentukan strategi mana yang dapat diambil untuk menyelesaikan masalah, kemudian menerapkannya sampai menemukan penyelesaian dari masalah.

$$
\text { Berbeda dengan model }
$$

pembelajaran konstruktivisme umumnya siswa hanya sebatas mendengar, menyimak, dan memperhatikan saja otomatis kemampuan anak berbeda. Siswa yang lebih banyak mendengar, dan menyimak secara seksama dimungkinkan dia lebih tinggi hasil belajarnya dibandingkan anakanak yang tidak mendengarkan. Hal ini sesuai yang dikemukakan (Saragih: 2016) "Tidak sedikit siswa memandang matematika sebagai mata pelajaran yang membosankan, menyeramkan bahkan menakutkan". Hal ini disebabkan karena siswa kurang terlibat di dalam kegiatan pembelajaran.

Solusi yang dapat dilakukan oleh guru untuk mengatasi hal tersebut adalah memodifikasi tahapan CPS menjadi lima tahap, yaitu klarifikasi (Clarify), mengeksplorasi ide (Ideate), mengembangkan (Develop), implementasi (Implement) dan memeriksa jawaban. Kemudian mengingatkan siswa untuk melakukan langkah memahami masalah dan memeriksa jawaban kembali pada saat mengerjakan tes kemampuan pemahaman konsep pemecahan masalah.

\section{Simpulan dan Saran Simpulan}

Berdasarkan hasil analisis dan pembahasan, maka dalam penelitian ini dapat disimpulkan bahwa berdasarkan hasil pengujian tersebut diperoleh kemampuan pemahaman konsep matematika dengan menggunakan model pembelajaran Creative Problem Solving lebih tinggi dari pada model pembelajaran Konstruktivisme.

\section{Saran}

Berdasarkan hasil penelitian yang telah diperoleh, peneliti dapat memberikan saran-saran sebagai berikut: (1) Bagi sekolah dan pihak guru khususnya guru matematika, hendaknya menggunakan model pembelajaran yang bervariasi khusuusnya dalam model pembelajaran salah satunya model pembelajaran Craetive Problem Solving (CPS) yang positif mampu dalam mengembangkan kemampuan pemahaman konsep matematika siswa. (2) Penelitian ini hanya ditunjukkan pada mata pelajaran matematika pada sub pokok bahasan perbandingan trigonometri, oleh karena itu sebaiknya penelitian juga dilakukan pada pokok bahasan matematika lainnya. (3) Sebaiknya proses pembelajaran yang menggunakan model pembelajaran CPS lebih sering diterapkan, sehingga kemampuan pemahaman konsep matematika siswa dapat meningkat karena siswa memperoleh suasana belajar yang lain dari biasanya dan dapat berinteraksi langsung dengan teman, bertukar pikiran dalam pemahaman konsep memecahkan suatu masalah. (4) Penelitian ini hanya menggunakan model pembelajaran Creative Problem Solving dan model pembelajaran Konstruktivisme saja dan pengontrolan variabel dalam penelitian ini yang diukur hanya pada aspek kemampuan pemahaman konsep matematika saja, sedangkan aspek lain tidak dikontrol. Bagi peneliti selanjutnya hendaknya melihat pengaruh penggunaan model pembelajaran CPS dan aspek matematika lainnya. 


\section{Daftar Pustaka}

Alhadad, S.F. 2010. Meningkatkan Kemampuan Representasi Multipel Matematis, Pemecahan Masalah Matematis, dan Self Esteem Siswa SMP Melalui Pembelajaran dengan Pendekatan Open Ended. Thesis, Bandung: Universitas Pendidikan Indonesia.

Depdiknas. 2006. Peraturan Menteri Pendidikan Nasional Republik Indonesia Nomor 22 Tahun 2006 tentang Standar Isi untuk Satuan Pendidikan Dasar dan Menengah. Jakarta: Depdiknas.

Fariah, N., \& Leonard. 2017. Pengaruh Frekuensi Pemberian Tes Formatif Terhadap Hasil Belajar Matematika. Prosiding Diskusi Panel Nasional Pendidikan Matematika, 589-598. http://doi.org/10.1177/1071181312 561467

Noer, S.H. 2009. Kemampuan Berpikir Kreatif Matematis: Apa, Mengapa, dan Bagaimana? Prosiding Seminar Nasional Penelitian, Pendidikan dan Penerapan MIPA Fakultas MIPA,16 Mei 2009, UNY Yogyakarta

Isrok'atun. 2012. Creative Problem Solving (Cps) Matematis. Prosiding Seminar Nasional Penelitian dan Pendidikan FMIPA Universitas Negeri Yogyakarta. 10 November 2012. Yogyakarta.

OECD. 2016. PISA 2015 : PISA Results in Focus. Tersedia: https://www.oecd.org/pisa/pisa2015-results-in-focus.pdf $[10$ Agustus 2017]
Suandito, W., Darmawijoyo, Purwoko. 2009. Pengembangan Soal Matematika Non Rutin di Sma Xaverius 4 Palembang. Jurnal Pendidikan Matematika, 3(2) : 113.

Subandriah, Marlina, Ratna. 2012. Analisis Soal-Soal Pada Buku Ajar Matematika Kelas VIII Ditinjau dari Aspek Kognitif. Skripsi. Surakarta: Universitas Muhammadiyah Surakarta.

Supardi. 2013. Aplikasi Statistika dalam Penelitian. Jakarta: Gramedia.

Treffinger, D. J., Isaksen, S.G. 2005. Creative Problem Solving: The History, Development, and Implications for Gifted Education and Talent Development. Gifted Child Quarterly, 49(4) : 342-353.

Treffinger, D., J., Isaksen, S., G.,\& Dorval, K., B., S. 2006. Creative Problem Solving : an Introduction, 4th Edition. Prufrock Press Inc: Texas. [online]. Tersedia https://books.google.co.id/books?hl $=\mathrm{id} \& l \mathrm{r}=\& \mathrm{id}=$ iZtqz7IuFcC\&oi=fnd $\& p g=P R 6 \& d q=$ strengths + and + wea kness+of+creative+problem+solvin g\&ots $=1$ sOi8andrv\&sig=nz8KDe9n 0CVKsMPJ2Vr6IuDEj88\&redir_es $\mathrm{c}=\mathrm{y} \# \mathrm{v}=$ onepage $\& \mathrm{q}=$ strengths $\% 20 \mathrm{a}$ nd $\% 20$ weakness $\% 20$ of $\% 20$ creative $\% 20$ problem $\% 20$ s olving $\& \mathrm{f}=$ false . [27 Februari 2017]

.2010. Creative Problem Solving $\quad\left(C P S \quad\right.$ Version $6.1^{\mathrm{TM})} \quad A$ Contemporary Framework for Managing Change 